Eva Brumercikova - Bibiana Bukova - Iwona Rybicka - Pawel Drozdziel*

\title{
MEASURES FOR INCREASING PERFORMANCE OF THE RAIL FREIGHT TRANSPORT IN THE NORTH-SOUTH DIRECTION
}

The article elaborates on measures aimed at increasing the performance of the rail freight transport carried out in the north-south direction. The measures are designed based on the implemented analyses focused on the analysis of the current situation of international trade and development of international transport as well as the analysis of the current situation of the European transport infrastructure. The north-south direction was selected due to the enormous increase of the transit road transportation.

Keywords: rail freight transport, road infrastructure congestion, intermodal transport line, north-south direction

\section{Introduction}

The global economy with growing liberalization brings along new logistic technologies as well as associated optimization of international transport. It is not driven only by the increasing competition within the transport market, but by many different external factors having impact on the international markets created by individual countries of the EU, as well. The external factors include unemployment, migration, air pollution etc. The growing global competition, volumes of transported goods as well as the capacity of the European transport infrastructure, bring about the conflicting situations for the production companies. Current approach is based on cooperation of individual transport modes. One of the possibilities is to use the transport capacity of the rail transport mode.

\section{Road infrastructure congestion}

In order to determine the level of congestion of the road infrastructure it is necessary to process an analysis, which is based on a national transport census carried out by the relevant road infrastructure administrator of a given country regularly every five years [1-2]. Consequently, the transport flows in international road transport are determined, based on the transport intensity within the given studied connections in the north-south direction and based on the available data on the structure of vehicles origin according to the vehicle registration numbers (hereinafter only VRN).

For the baseline comparison it is also necessary to determine the basic indicator of the labour division in international transport, according to individual modes of transport as well as specific countries. Specific values of the labour division in selected countries in the area of international transport are given in Figure 1. The source data for the figure are derived from available information of 2017 depending on the transport performance [3]

\subsection{Analysis of the road infrastructure congestion in the Slovak Republic}

In 2015 the Slovak Roads Administration carried out the most recent traffic census in the road network and in 2013 it published a document titled "Forecasting of Future Intensities within the Road network by 2040" [4]. For the sake of the objective of this article it is necessary to consider the outputs of the relevant sections, as well as regions for the current situation as well as expected development of the road infrastructure congestion. Information from the toll systems is not available due to refusal of relevant sources to provide it.

Figure 2 represents a model situation of the road infrastructure congestion elaborated in 2014 with the assistance of the Research Institute of Transport.

The graphical representation is based on the traffic census of 2010, as well as the document "Forecasting of Future Intensities in the Road Network by 2040", which includes coefficients of growth of transport intensity in individual Slovak regions given according to the forecasting methodology of the Slovak Roads Administration [6].

When comparing the average values of selected census stations of 2010 and 2015 as well as in comparing the forecasted development of intensity, it is possible to calculate a $5 \%$ increase of the number of trucks in case of D1 and a $9 \%$ decrease of the number of vehicles in case of R1. The estimated development according to the forecast is $13 \%$ in the case of D1 and $14 \%$ in the case of R1. The deviation in the forecast and census of vehicles in individual years can be caused by the census inaccuracy or the failure of the forecast.

\subsection{Analysis of the road infrastructure congestion in Hungary}

In 2015 the Hungarian Roads Administration (Kozlekedesi koordinacios kozpont - hereinafter only KKK) carried out a

\footnotetext{
* ${ }^{1}$ Eva Brumercikova, ${ }^{1}$ Bibiana Bukova, ${ }^{2}$ Iwona Rybicka, ${ }^{2}$ Pawel Drozdziel

${ }^{1}$ Department of Railway Transport, Faculty of Operation and Economics of Transport and Communications, University of Zilina, Slovakia

${ }^{2}$ Politechnika Lubelska, Lublin, Poland

E-mail: bibiana.bukova@fpedas.uniza.sk
} 


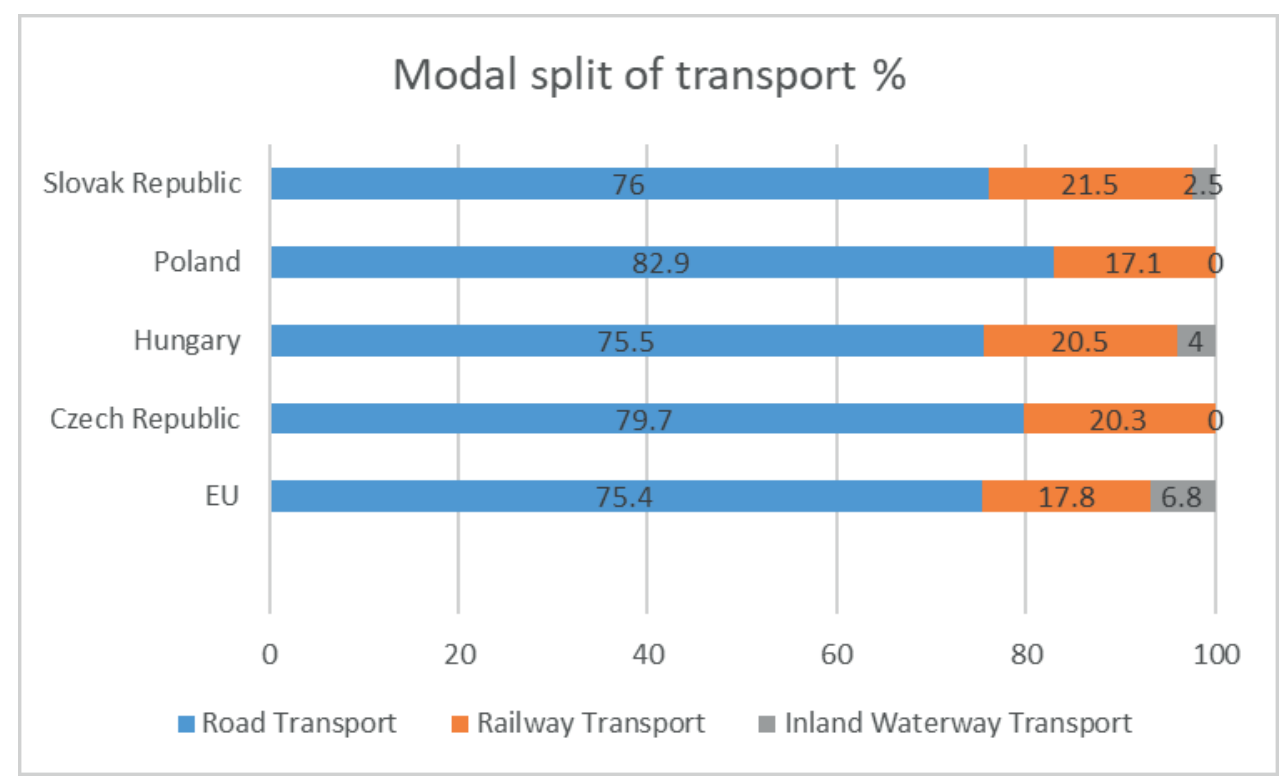

Figure 1 Division of labour in international transport [3]

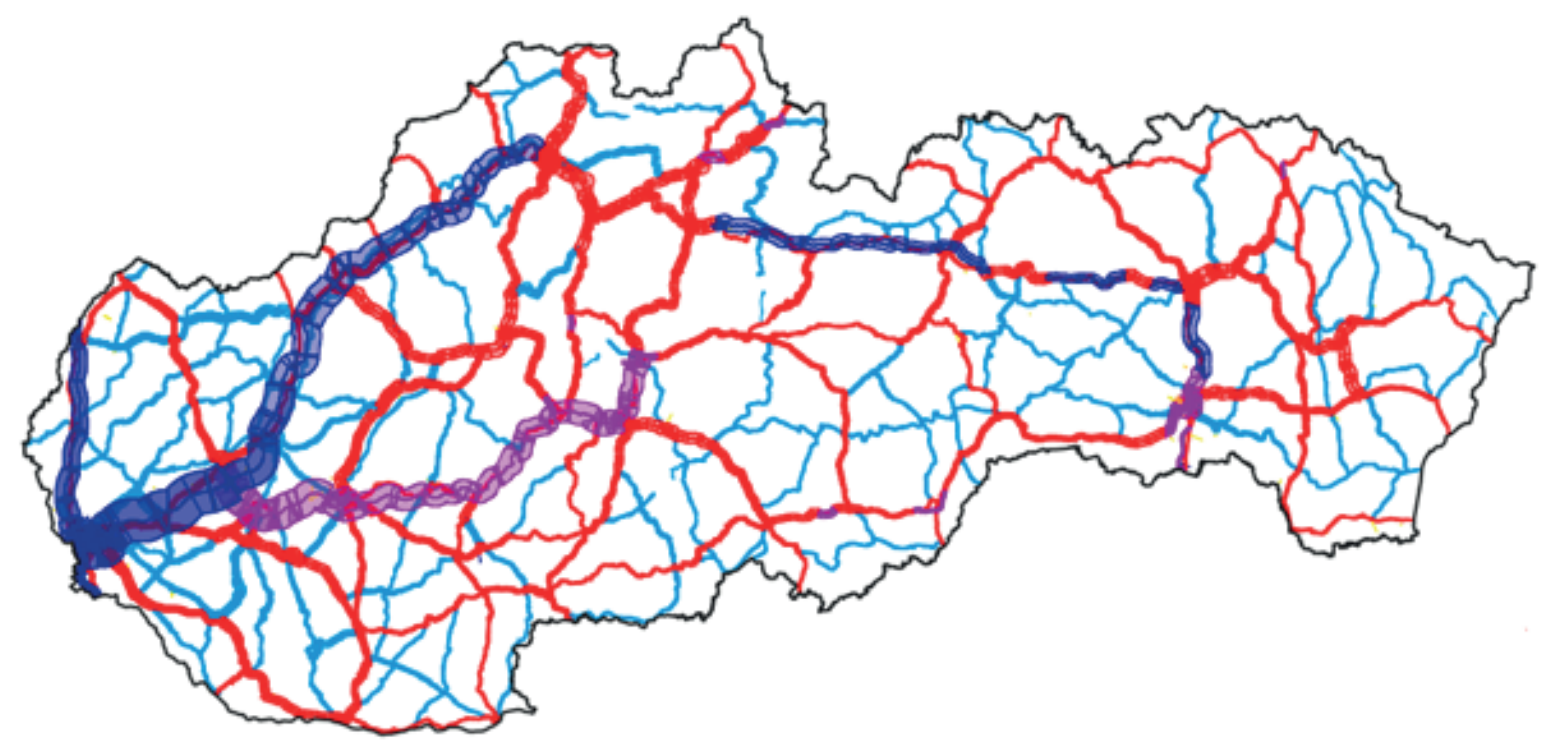

Legend: The total number of vehicles per 24 hours

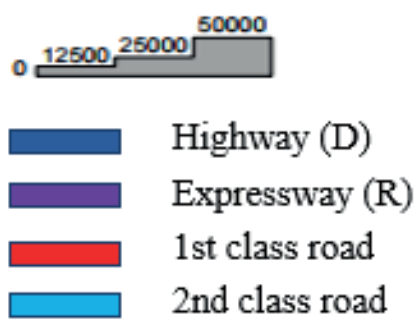

Figure 2 The map of the road network congestion 2014 - Slovakia [5]

national network-wide survey of the road infrastructure congestion as well as a survey of the state registration origin of vehicles over 12 tons having the obligation of the toll paying on the motorways and 1st class roads. The national pertinence of road vehicle combinations is graphically illustrated in Figure 3.
It is evident from the chart that $40 \%$ of trucks that entered the road network in Hungary in 2015 had the VRN originated in Rumania, $10 \%$ of vehicles originated in Poland, whereas the following $10 \%$ came from Bulgaria, $8 \%$ of vehicles have their origin in the Slovak Republic and 6\% in Serbia [7]. 


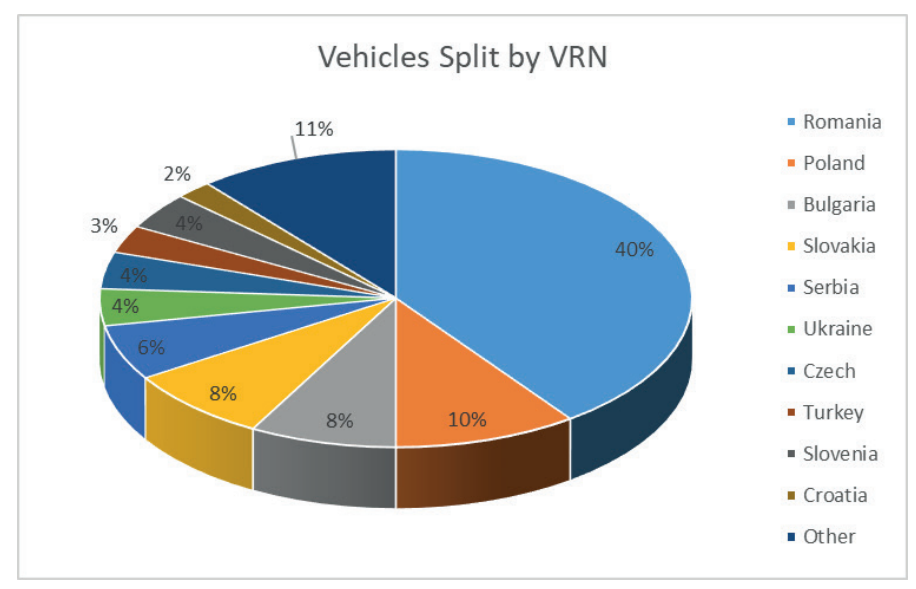

Figure 3 Vehicles split by VRN [7]
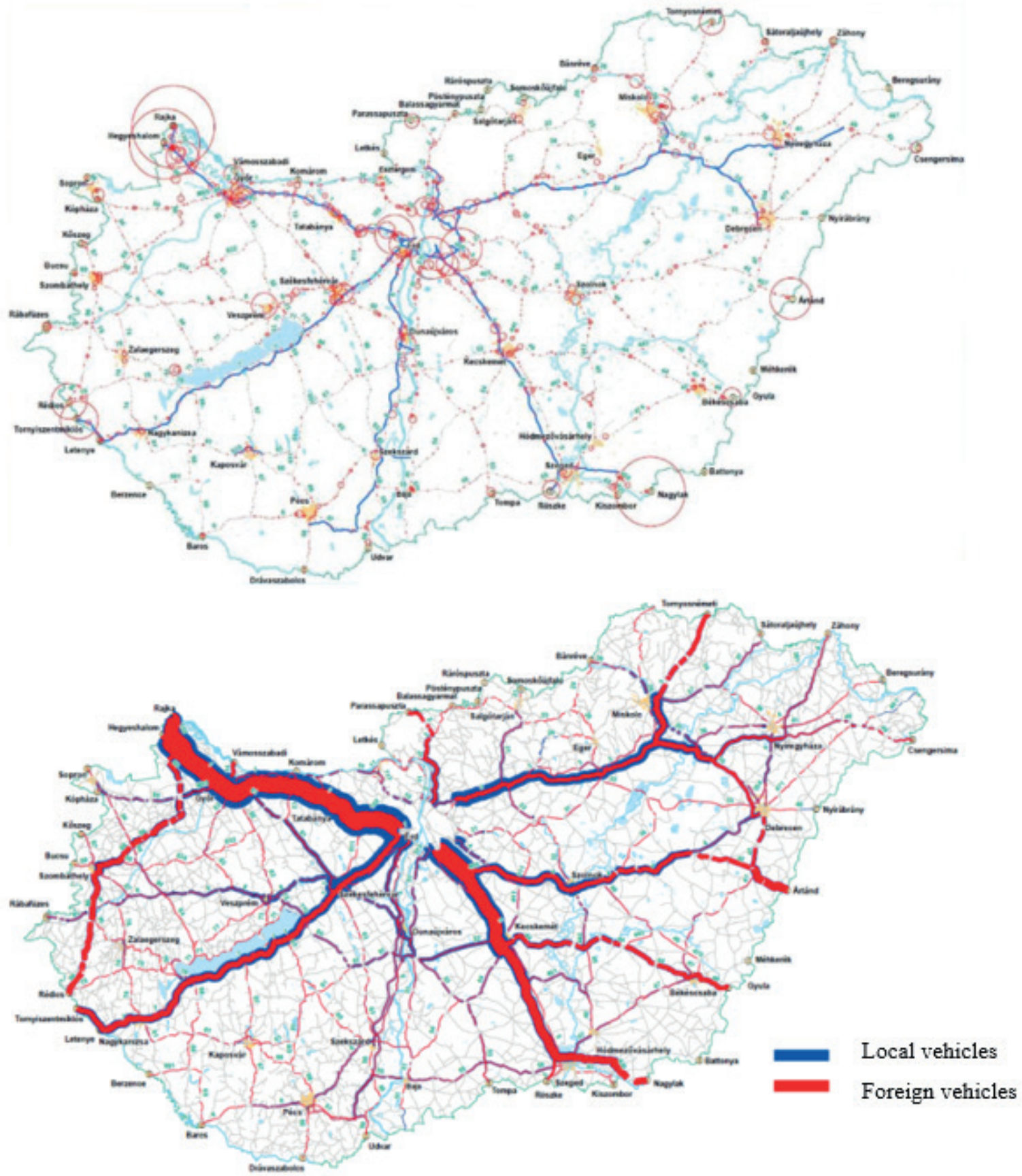

Figure 4 The map of the road infrastructure congestion - Hungary [8] 


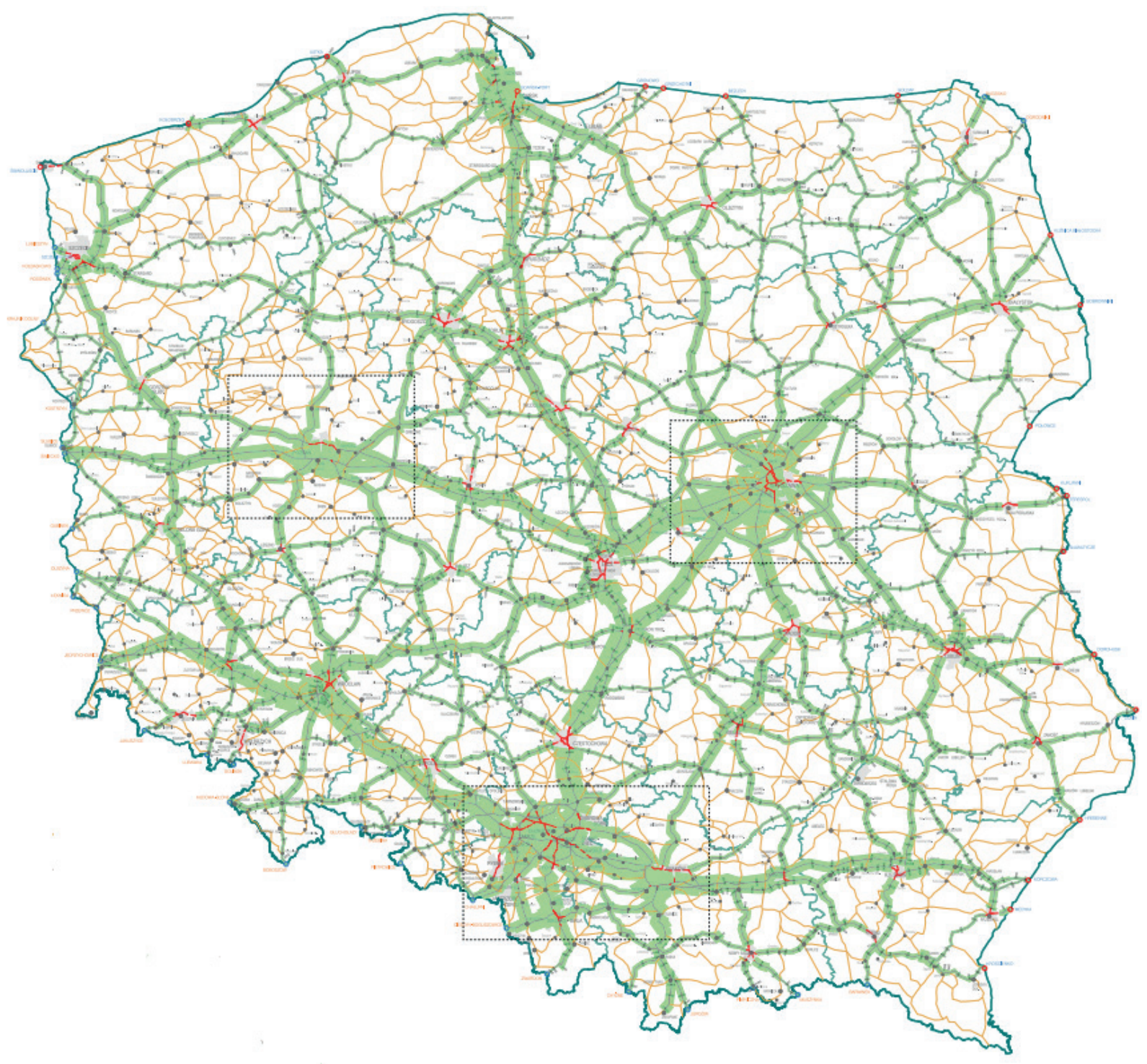

Figure 5 The result of traffic census in 2015 [9]

When considering the data of the directional survey of KKK it is evident that the highest intensity of the transit road semi-trailer combinations of over 12 tons on the road network of Hungary passes through the border crossings Rajka (Rusovce in Slovakia) and Hegyeshalom (Nickelsdorf in Austria) upon entry/ exit from the border crossings Nagylak (Nadlac in Romania) and Artand (Bors in Romania).

Figure 4 shows a map from the KKK directional survey, whose first part depicts the intensity of over 12 ton trucks' destinations at the border crossing points by the size of the circle diameter. In the second part the map depicts the intensity of trucks divided by local and foreign VRN.

\subsection{The analysis of the road infrastructure congestion in Poland}

The Polish Roads Administration (Generalna dyrekcia drog krajowych i autostrad - hereinafter only GDDKA) carried out the traffic census last in 2015 (Figure 5). Details of the traffic census cannot be disclosed. The data have been processed into the graphic representation of the transport intensity in the V4 (Visegrad Group - Slovakia, Czechia, Poland, Hungary) countries in Figure 6.

\subsection{The analysis of the road infrastructure congestion in the Czech Republic}

The Directorate of Roads and Highways of the Czech Republic (hereinafter only ŘSD) carried out its most recent traffic census in 2010. For 2015 there is no data, the study has not been completed by the time of accomplishment of the project underlying the article. The information from the toll systems is not available [10]. The data have been processed into the graphical representation of the transport intensity in the V4 countries in Figure 5. 


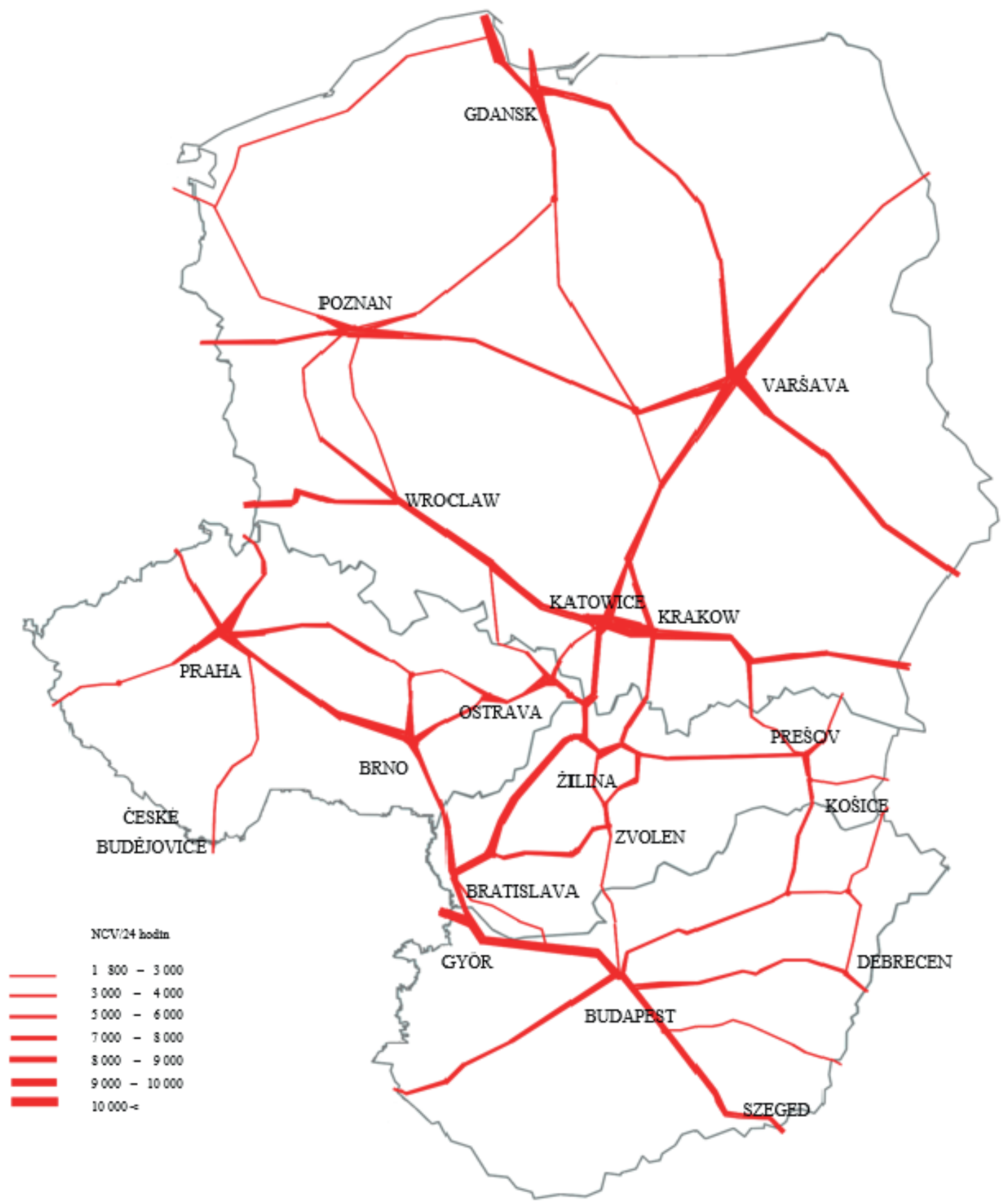

Figure 5 The map of V4 countries with the transport intensity

\subsection{Result of analysis}

Based on the provided data by e-mail communication, as well as annexes to the transport census studies, the graphical image in Figure 5 - the Map of V4 countries with the transport intensity has been set up. The methodology is based on determining the selected census stations in V4 countries and the consequent arrangement of intensities by the boldness of lines, which are given in the Figure 5 legend. The transport intensity in the Czech Republic was determined using the study of 2010, therefore the informative value of the graphical representation in the Czech Republic is not comparable with the rest of the V4 countries, nevertheless it has been included here for reasons of general overview.

Identified transit paths in the north-south direction, which pass through the territory of the Slovak Republic, correspond with the conclusions of the strategic document "The Strategic Plan of Transport Infrastructure Development of the Slovak Republic by $2020 ”$.

\section{A proposal for an intermodal transport line}

An increase in the train capacity utilisation (e.g. an increase in the net tonnes of products or number of containers) can 


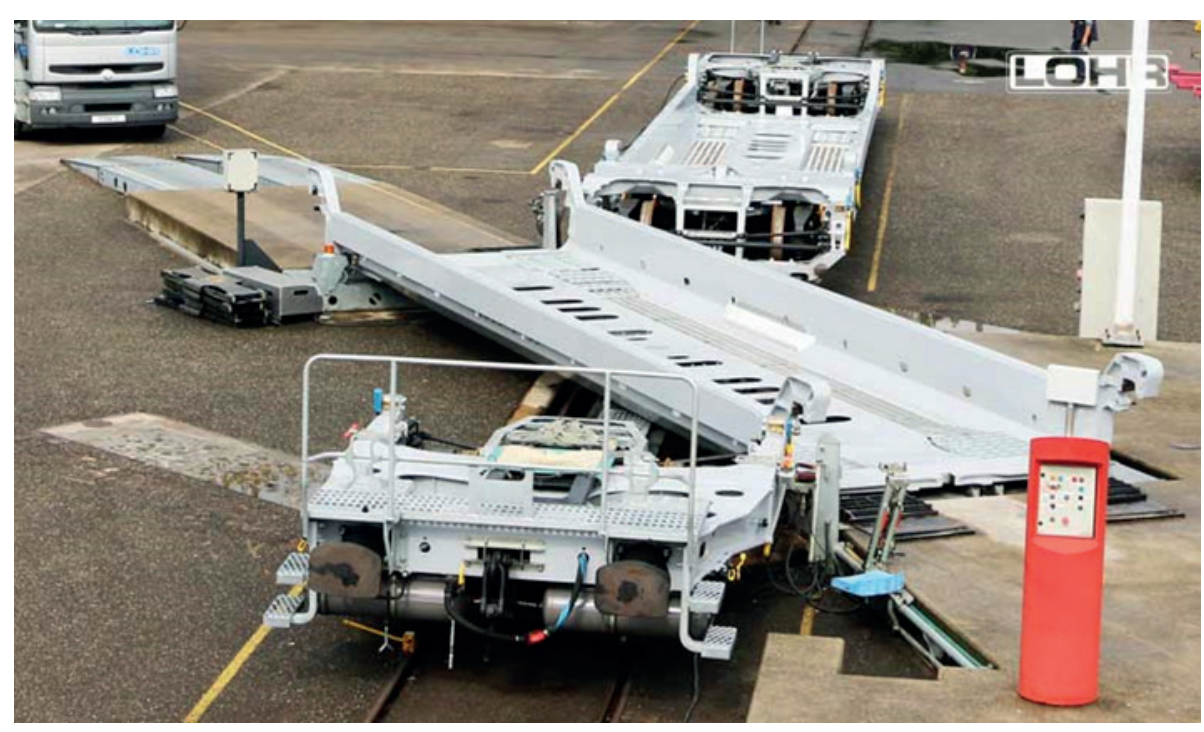

Figure 6 The Modalohr wagon [14]

be achieved only if sufficient rail infrastructure capacity exists (norms of length and weight).

A change in operating performance due to the increase in the train capacity utilisation is inversely proportional to the train weight. If the weight of the train increases by about $\Delta$, the number of train kilometres is reduced. We can define this according to Equation (1):

$$
\begin{aligned}
\sum \text { trkm }^{1} & =\frac{\sum \text { grtkm }_{z}}{Q_{v l}^{1}}=\frac{\sum \text { grtkm }_{z}}{Q_{v l}^{1} *(1+\Delta)} \\
& =\sum \operatorname{trkm}^{0} * \frac{1}{1+\Delta}
\end{aligned}
$$

where:

$\sum$ trkm $^{1}$ - train kilometres after the increase,

$\sum$ trkm $^{0}$ - train kilometres before the increase,

$\sum$ grtkm - gross tonnage kilometres (beside the locomotive),

$Q^{o} v l$ - weight of the train before the increase,

$Q^{l} v l$ - weight of the train after the increase.

Economic indicators change through the lower fees for the railway infrastructure (in the EU countries, train kilometres are the basic parameter by which the fees for the railway infrastructure are calculated), increased labour productivity and thus lower labour costs. Some costs can be higher, such as the energy cost (problems with accelerating resistance) [11].

Based on the conclusions of the analysis, the core proposal of this article is to launch an intermodal transport line between the agglomerations of Budapest and Gliwice [12].

Budapest area was selected due to an optimal accessibility of logistic centres in the vicinity of the intermodal transport terminal BILK Budapest, which concurrently provides for a possibility of trans-loading of semi-trailers with conventional body in the WIPPEN transport system. In comparison to the lines of the RO-La system operated in the past in the MAV network, with its terminal built in the Kiskundorozsma railway station, $17 \mathrm{~km}$ from the state borders with Rumania, the logistic centre BILK Budapest provides better accessibility for road semitrailer combinations driving from the port in Koper, Slovenia.
Gliwice agglomeration (PL) was determined based on the currently operated tri-modal terminal of intermodal transport - PCC Intermodal SA. The terminal is located $22 \mathrm{~km}$ from Katowice, a city, which, in the analysis of the road infrastructure intensity, demonstrated average values exceeding 10000 truck at the measuring stations within the centre of the agglomeration.

A proposal for integration of the intermodal transport line Budapest - Gliwice in the planned lines of the company Lohr Group - the company Lohr Group was established in France and at present it provides comprehensive innovative solutions in the field of logistic services and intermodal transport. Figure 6 shows a wagon of the company Lohr Group located within a small terminal with moving ramps. The Modalohr wagon disposes with the ability of turning its middle part and thereby it enables simplified loading of vehicle combinations and semitrailers and trucks.

The company Lohr Group currently operates intermodal transport lines in the form of RO-MO and semitrailer transport system in its own flat wagons, which represent a technical compromise between the Saadkms and Sdgnss wagons. The lowered floor of the wagon to $225 \mathrm{~mm}$ from the top of the rail enables loading of the vehicle combinations horizontally, as well as loading of individual semi-trailers [13].

Figure 6 shows the Modalohr wagon and an example of the ramp positioning for the semi-trailer loading.

Figure 7 illustrates the planned, as well as currently operated, lines of the intermodal transport, which the company Lohr Group plans to operate using its own technical facilities and by construction of terminals from its own financial resources.

The company Lohr Group used the red colour to represent currently operated lines of the intermodal transport, the blue lines are the lines planned operated lines in the short-term and in yellow there are the lines, which have been planned in the long-term. The planned line of the intermodal transport passing through the territory of Hungary, Slovakia and the Czech Republic has been routed from the port in Istanbul through Bulgaria and Serbia to the logistic centre in the city of Poznan, in Poland.

For the territory of Slovakia a transit route has been planned, from the border passage station in Sturovo up to the border 


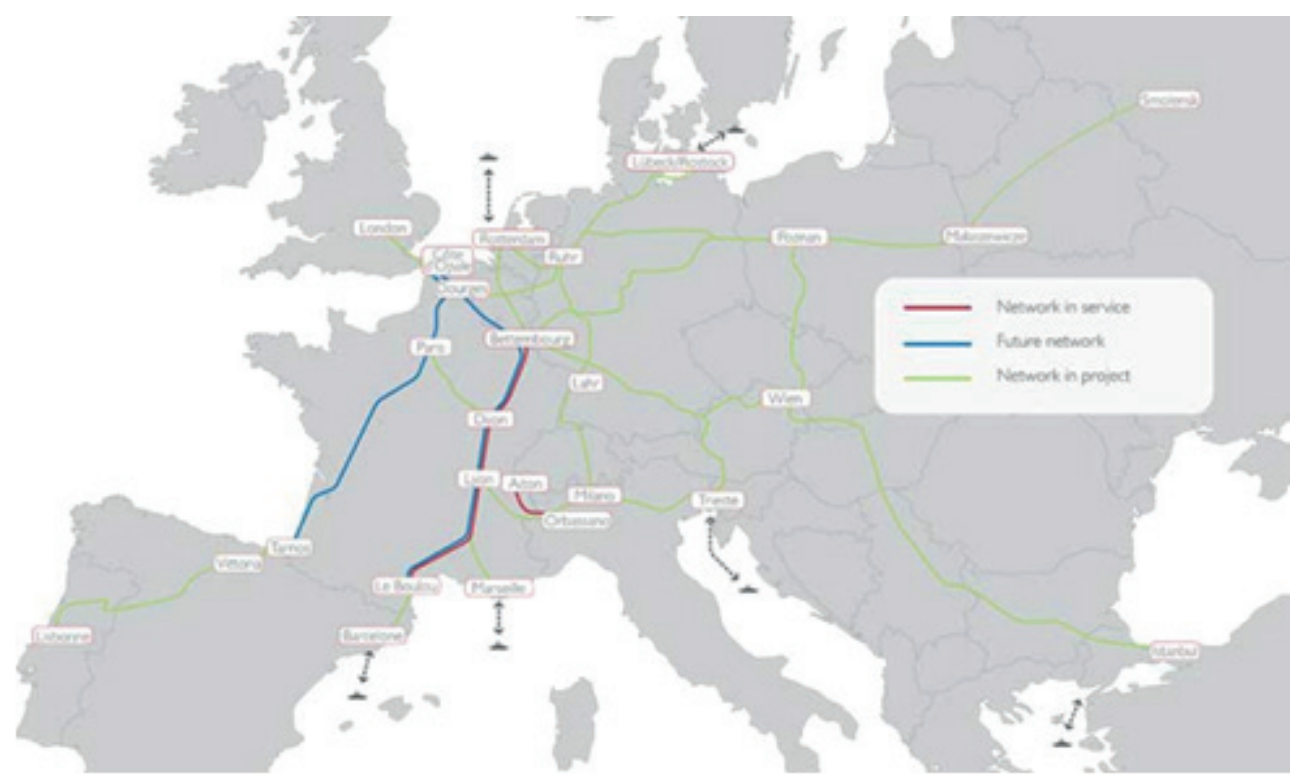

Figure 7 The map of the planned Modalohr routes [14]

passage station in Devinska Nova Ves - i.e. $148 \mathrm{~km}$. The routing has been planned alternatively through Budapest - Gyor - PPS (Border Crossing Station) Hegyeshalom - PPS Nickelsdorf (in Austria) due to the fact that inclusion of Vienna agglomeration is strategically more convenient for reasons of larger coverage of the territory in respect to dispatching and distribution of goods in road vehicle combinations [15-16].

\section{Conclusion}

Due to the growing economic globalization, the priority of production companies as well as shippers is to increase the quality of goods production as well as service delivery. The current situation of the European transport infrastructure does not fully enable to meet this priority. Based on the situational analysis, the article introduces a measure for increasing the performance of the rail freight transport in the north-south direction. The measure implies establishing a new intermodal transport line in the transportation of the so-called basket Wippen wagons. For the sake of the maximal accessibility and flexibility, a transiting route has been selected, passing through the Slovak Republic from Hungary to Poland. For launching of the intermodal transport line, all the operating conditions there have been considered, including the need of a contracted road transport operator, as well as concurrent coordination of activities with those of the logistics centres. In the case of establishment of such a line of intermodal transport, shortcomings in the area of rail infrastructure related to the insufficient capacity of border passage stations, were determined. Due to this deficiency it is proposed to introduce a fee for immobilization of the rolling stock.

\section{Acknowledgment}

This paper was developed under the support of project: Centre of excellence for systems and services of intelligent transport II., ITMS 26220120050 supported by the Research \& Development Operational Programme funded by the ERDF.

\section{References}

[1] DOLINAYOVA, A., CAMAJ, J., DANIS, J. Evaluation of investment efficiency in the new database solution for rail freight transport in the context of globalization (in Slovak). 16th International Scientific Conference Globalization and its Socio-Economic Consequences : proceedings. 2016. ISBN 978-80-8154-191-9, p. 383-390.

[2] NESTEROVA, N. S., CONCHARUK, S. M., ANISIMOV, V. A., ANISIMOV, A. V. Strategy development management of multimodal transport network. 5th International Scientific Conference Integration, Partnership and Innovation in Construction Science and Education : proceedings [online]. Vol. 86. MATEC Web of Conferences, 2016. eISSN: 2261-236X. Available from: https://doi.org/10.1051/matecconf/20168605024

[3] Database - Eurostat [online]. [Viewed 2019-02-04]. Available from: https://ec.europa.eu/eurostat/data/database

[4] BRUMERCIK, F., LUKAC, M., KRZYSIAK, Z., KRZYWONOS, L. Model of integrated transportation system. Communications - Scientific Letters of the University of Zilina [online]. 2017, 19(2), p. 23-26. ISSN 1335-4205, eISSN 2585-7878. Available from: http://komunikacie.uniza.sk/index.php/communications/article/view/177

[5] Transport model - Ministry of Transport and Construction of the Slovak Republic [online]. [Viewed 2019-02-04]. Available from: https://www.mindop.sk/ministerstvo-1/doprava-3/dopravne-modelovanie/dopravny-model-sr 
[6] GASPARIK, J., LUPTAK, V., MESKO, P. New methodology for assessing transport connections depending on the integrated transport network. 3rd International Conference on Traffic and Transport Engineering : proceedings. 2016. ISBN 978-86-9161533-8, p. 388-392.

[7] KRZYSIAK, Z., BARTNIK, G., SAMOCIUK, W., ZARAJCZYK, J., PLIZGA, K., RACHWAL, B., WIERZBICKI, S., KRZYWONOS, L., BRUMERCIK, F.: Analysis of explosion hazard at the liquid fuel station (in Polish). Przemysl Chemiczny [online]. 2017, 96(2), p. 279-282. ISSN 0033-2496, e-ISSN 2449-9951. Available from: https://doi.org/10.15199/62.2017.2.5

[8] GUBOVA, K., RICHNAK, P. Development and use of intangible assets in the conditions of globalization. 16th International Scientific Conference Globalization and its Socio-Economic Consequences : proceedings. 2016. ISBN 978-80-8154-191-9, p. 572579.

[9] General Director for National Roads and Motorways Website (Generalna Dyrekcja Drog Krajowych I Autostrad) [online]. Available from: www.gddkia.gov.pl

[10] CEMPIREK, V., NACHTINGALL, P., NOVAK, P., PLUHAR, M. The comparison of public rad and railway transport costs. 3rd International Conference on Traffic and Transport Engineering : proceedings. 2016. ISBN 978-86-916153-3-8, p. 855-860.

[11] DOLINAYOVA, A.: Optimisation of business processes and services in the rail transport market from two points of view: economic efficiency and management. Sustainable Rail Transport Conference : proceedings [online]. Springer, Cham, 2016. ISBN 978-3-319-58642-7, eISBN 978-3-319-58643-4, p. 31-44. Available from: https://doi.org/10.1007/978-3-319-58643-4_3

[12] LIUDVINAVICIUS, L., DAILYDKA, S., SLADKOWSKI, A. New possibilities of railway traffic control system. Transport Problems. 2016, 11(2), p. 133-142. ISSN 1896-0596, eISSN 2300-861X.

[13] GONCHAROV, A. A., YUNDA, A. N., KOMSTA, H., ROGALSKI, P. Effect of structure on physicomechanical properties of transition metals diboride films. Acta Physica Polonica A [online]. 2017, 132(2), p. 270-273. ISSN 0587-4246, eISSN 1898-794X. Available from: https://doi.org/10.12693/APhysPolA.132.270

[14] The Lohr System Terminals - Lohr Group [online]. Available from: https://lohr.fr/lohr-railway-system/the-lohr-system-terminals

[15] GNAP, J., KALASOVA, A., GOGOLA, M., ONDRUS, J. The Centre of excellence for transport service and control. Communications : scientific letters of the University of Zilina [online]. 2010, 12(3A), p. 116-120. ISSN 1335-4205, eISSN 2585-7878. Available from: http://komunikacie.uniza.sk/index.php/communications/article/view/956

[16] ONDRUS, J., DICOVA, J. Potential of prediction quantification and trends in transport requirements as tool of transport management and development Transport and Telecommunication [online]. 2013, 14(4), p. 316-324. ISSN 1407-6160. Available from: https://doi.org/10.2478/ttj-2013-0027 